\title{
OPTIMIZATION OF MIXING TEMPERATURE AND SONICATION DURATION IN LIPOSOME PREPARATION
}

\section{OPTIMASI SUHU PENCAMPURAN DAN DURASI SONIKASI DALAM PEMBUATAN LIPOSOM}

\author{
Dina Christin Ayuning Putri ${ }^{1 *}$, Rini Dwiastuti ${ }^{1}$, Marchaban², Akhmad Kharis Nugroho \\ ${ }^{1}$ Faculty of Pharmacy, Universitas Sanata Dharma, Campus 3 Paingan, Maguwoharjo, Depok, \\ Sleman, Yogyakarta, 55282 \\ ${ }^{2}$ Faculty of Pharmacy, Universitas Gadjah Mada, Yogyakarta, 55281
}

Received September 13, 2017; Accepted October 31, 2017

\begin{abstract}
Liposomes are a delivery system used in pharmaceutical products and cosmetics. Liposomes have many advantages such as increase stability and efficacy, can be targeted to reduce toxicity and increase accumulation at the target site and are biocompatible. Preparation of liposomes can be done by conventional or new methods which are still being developed. Conventional methods often require a long time and organic solvents which may be toxic. Heating (Mozafari method) is one of the new methods developed in the manufacture of liposomes without organic solvents. Mixing temperature can affect the physical properties of liposomes. The particle size has become one of the important physical properties because it affects the absorption of the drug. Sonication is an easy method of choice in reducing the size of liposomes. Optimization of mixing temperature and duration of sonication in liposomes' preparation using new heating methods and sonication were performed by factorial design with 2 factors and 3-levels to obtain optimal liposome size. Data were analyzed with two-way ANOVA. The results showed that both mixing temperature and sonication duration significantly affect liposome size, but the interaction was not statistically significant. Data analysis also showed that mixing temperature, sonication, and their interaction do not affect the polydispersity index of liposome. Results showed the optimum mixing temperature and sonication duration that can produce liposomes with size below $100 \mathrm{~nm}$ is at $60^{\circ} \mathrm{C}$ for 30 minutes.
\end{abstract}

Keywords: duration, liposome, mixing, sonication, temperature

\begin{abstract}
ABSTRAK
Liposom merupakan sistem penghantaran obat yang sering dikembangkan dengan berbagai kelebihan dalam meningkatkan efektifitas, stabilitas, dan kelarutan suatu obat. Pembuatan liposom dengan metode konvensional, membutuhkan tahapan rumit, waktu yang lama, serta memungkinkan adanya residu pelarut organik yang tertinggal. Metode pemanasan merupakan salah satu metode baru yang dikembangkan dalam pembuatan liposom tanpa menggunakan pelarut organik dan mudah untuk dilakukan. Suhu pencampuran berpengaruh terhadap sifat fisik liposom yang dihasilkan. Ukuran partikel menjadi salah satu sifat fisik yang penting untuk diperhatikan. Salah satu usaha untuk memperkecil ukuran partikel adalah dengan cara sonikasi. Tujuan penelitian ini adalah untuk memperoleh suhu pencampuran dan lama sonikasi yang optimal dalam pembuatan liposom dengan metode pemanasan. Respon ukuran liposom pada masing-masing perlakuan dianalisis agar diperoleh suhu pencampuran dan lama sonikasi
\end{abstract}

*Corresponding author: Dina Christin Ayuning Putri

Email: dinachristin@usd.ac.id 
optimal. Analisis varian dilakukan untuk mengetahui apakah suhu pencampuran dan durasi sonikasi mempengaruhi ukuran partikel, Hasil menunjukkan bahwa suhu pencampuran dan lama sonikasi berpengaruh terhadap ukuran liposom yang dihasilkan, namun interaksi keduanya tidak berpengaruh. Suhu pencampuran dan durasi sonikasi optimal yang dapat menghasikan liposom dengan ukuran kurang dari $100 \mathrm{~nm}$ adalah pada $60^{\circ} \mathrm{C}$ selama 30 minutes.

Kata kunci: durasi, liposom, pencampuran, sonikasi, temperature

\section{INTRODUCTION}

Liposome is a vesicle which is used as a delivery system for drugs and cosmetics (Barenholz, 2001). Liposomes are made from phospholipids. Liposome's permeability has an important role to increase encapsulation efficiency of hydrophilic drugs (Eloy et al., 2014). There are many advantages using liposomes as a delivery system, such as it can be targeted, is less toxic, biocompatible, increases efficacy and increases stability (Akbarzadeh et al., 2013).

Soy lecithin is a phospholipid often used in the formulation of liposomes because it has good stability against variations in $\mathrm{pH}$ or the concentration of salt in the formula. Also, it is easily obtained from a natural source (Machado et al., 2014). Soy lecithin contains unsaturated fatty acids which have a high compatibility in the body and good penetration (Kang et al., 2005).

Preparation of liposomes can be done by conventional or new methods which are still being developed. Conventional methods include the Bangham method, reverse phase evaporation, and solvent injection, which often need a long time in the preparation and require organic solvents which leave residues that might be toxic (Mozafari, 2005; 2010). The heating method (Mozafari method) is one of the new methods developed for the preparation of liposomes without organic solvents and can be used to make liposomes containing enzymes, vaccines, or other compounds that are sensitive to organic solvents (Colas et al., 2007). Preparation of liposome using the Mozafari method can produce about $600 \mathrm{~nm}$ size of liposome.

Particle size has become one of the physical properties that needs to be considered in the formulation of liposomes. Optimal size of liposomes in various studies as drug delivery systems is between $50-100 \mathrm{~nm}$. Various ways to reduce particle size can be done. One is by sonication, which is practical and easy to do (Akbarzadeh et al., 2013). Dwiastuti et al. (2016) described using a combination of heating method and sonication to prepare a small liposome. The combination of those methods can produce smaller liposome with mean size $99.76 \pm 35.57 \mathrm{~nm}$.

A variety of conditions in the preparation and composition can affect the properties of liposomes such as particle size, types of liposomes, encapsulation efficiency, etc. An evaluation by the Placket Burman design shows that various factors such as composition of soy lecithin, mixing speed, mixing duration and mixing temperature affect the physical properties of a liposome (Jahadi et al., 2012).

Mixing temperature plays an important role in the preparation process because the phospholipid liposomes have a transition temperature to form a liposome. Soy lecithin has a transition temperature at $50-60^{\circ} \mathrm{C}$. At temperatures less than $50^{\circ} \mathrm{C}$, soy lecithin dispersion forms a gel phase, while above the transition temperature, it will form a liquid crystal phase. The membrane changes from the gel phase to liquid crystal phase. In the liquid phase, each molecule can move more freely then form lipid layers to become liposome. This stage is a critical point when formulating liposomes, so mixing temperature needs to be optimized (Knight, 1981).

Sonication is an easy method used to reduce the size of liposomes. When sonicated, the liposomes will be exposed to ultrasonic waves. The ultrasonic waves have energy that can break the liposomes from large sizes into smaller. A liposome size should not be too 
small, related to the amount of drug that could be encapsulated, so it needs to be optimized for the duration of sonication (Shashi et al., 2012).

Mixing temperature and duration of sonication in liposome's preparation using the new combination heating method and sonication needs to be optimized, to obtain an optimum temperature mixing and sonication time, which can be used as a standard condition in making liposomes using the novel method of heating and sonication.

\section{METHODS}

\section{Materials}

Materials used in this study are lecithin (Nacalai Tesque, Inc., Japan) and redistilled water.

\section{Instrumentations}

Instruments used in this study are various glassware (Pyrex), blender (Waring), Ultraturax, Sonicator (Elmasonic), Particle Size Analyzer (Horiba SZ-100).

\section{Optimization of mixing temperature and sonication duration}

This study used a factorial design with two factors and three levels. Each was performed with three replications. The determination of high, medium and low levels can be seen in Table I.

The study design (Table II) is made with 9 conditions based on the high, medium, and low levels of each factor. Each experiment tries a combination of conditions for each factor. Preparation of liposome with different conditions used the same formula (Table III). Formula and liposome preparation methods used in this study are based on Dwiastuti et al. (2016).

Liposomes were prepared by dispersing lecithin in redistilled water with a variety of temperatures using laboratory blender for one minute, then the solution was homogenized with Ultraturax for 1 minute and sonicated with variations of mixing temperature and sonication duration.

\section{Determination of liposome size}

Determination of liposome size and their distribution is carried out by using a particle size analyzer (PSA) Horiba SZ-100 in LPOMK UII. Total of 0.5

$\mu \mathrm{L}$ of liposomes were put into a $25 \mathrm{~mL}$ plum flask, then added redistilled water and mixed. A total of $2 \mathrm{~mL}$ solution was poured into the cuvette to be measured. The expected liposome size is less than $100 \mathrm{~nm}$ (Jufri, 2004) with a polydispersity value $<0.3$ (Badran, 2014).

Table I. Factors Used in the Study and Determination of Level

\begin{tabular}{cccc}
\hline Factor & Level -1 & Level 0 & Level +1 \\
\hline Mixing temperature & $50^{\circ} \mathrm{C}$ & $60^{\circ} \mathrm{C}$ & $70^{\circ} \mathrm{C}$ \\
Sonication duration & 20 minutes & 30 minutes & 40 minutes \\
\hline
\end{tabular}

Table II. Study Design

\begin{tabular}{ccc}
\hline Mixing condition & $\begin{array}{c}\text { Mixing Temperature } \\
\left({ }^{\circ} \mathrm{C}\right)\end{array}$ & $\begin{array}{c}\text { Sonication duration } \\
(\text { minute })\end{array}$ \\
\hline 1 & 50 & 20 \\
2 & 50 & 30 \\
3 & 50 & 40 \\
4 & 60 & 20 \\
5 & 60 & 30 \\
6 & 60 & 40 \\
7 & 70 & 20 \\
8 & 70 & 30 \\
9 & 70 & 40 \\
\hline
\end{tabular}

*Temperature used in dispersing lecithin and sonicating the mixture 
Table III. Formula of Liposome

\begin{tabular}{cc}
\hline Material & Quantity \\
\hline Lecithin & 6.8 gram \\
Redistilled water & $100 \mathrm{~mL}$ \\
\hline
\end{tabular}

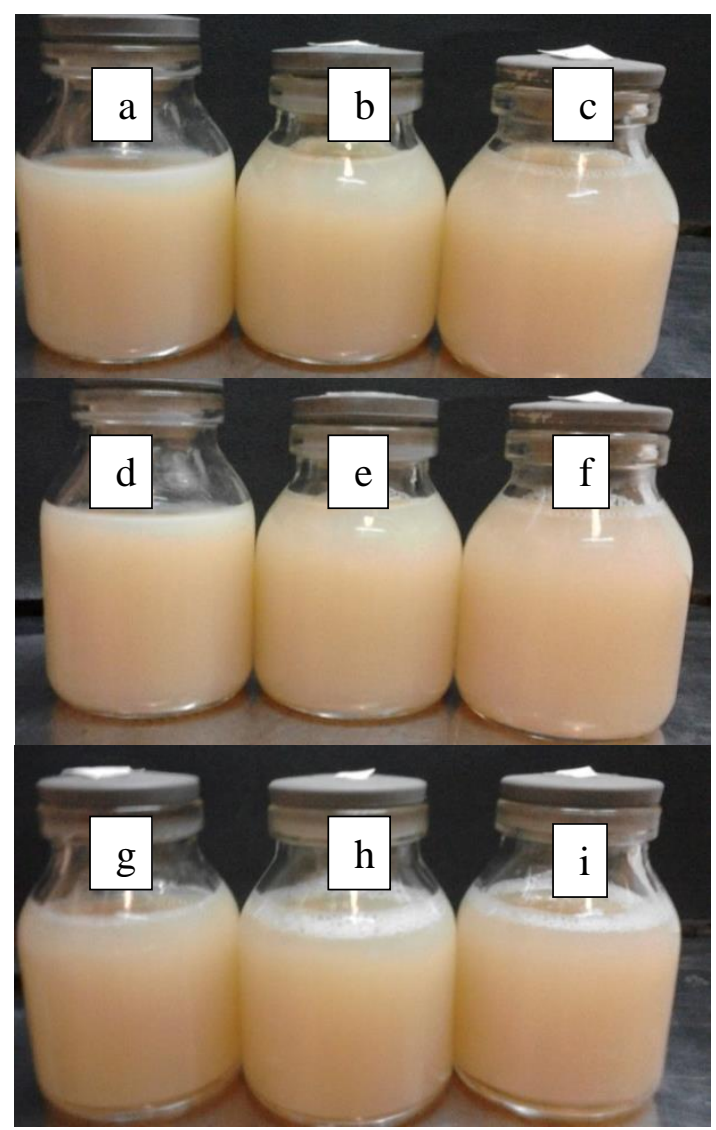

Figure 1. Physical appearance of liposome with variation of mixing temperature and sonication duration. (a. $50^{\circ} \mathrm{C}$ for 20 minutes; b. $50^{\circ} \mathrm{C}$ for 30 minutes; c. $50^{\circ} \mathrm{C}$ for 40 minutes; d. $60^{\circ} \mathrm{C}$ for 20 minutes; e. $60^{\circ} \mathrm{C}$ for 30 minutes; f. $60^{\circ} \mathrm{C}$ for 40 minutes; g. $70^{\circ} \mathrm{C}$ for 20 minutes; h. $70^{\circ} \mathrm{C}$ for 30 minutes; i. $70^{\circ} \mathrm{C}$ for 40 minutes)

\section{Data analysis}

Data were analyzed using two-way ANOVA (with Microsoft Excel) to determine the significant differences of the effect of mixing temperature and duration of sonication or a combination of both on the size of the resulting liposomes.

\section{RESULTS AND DISCUSSION}

The Mozafari method or also known as the heating method is a simple and reproducible method to prepare liposomes. Jahadi et al. (2014) studies, using the Placket Burman method for optimization, determined that there are many factors that affect the physical properties of liposomes, such as composition of phospholipid, mixing temperature, mixing duration, stirrer/tank diameter, and speed of stirrer.

Preparation of liposome with the heating method can be conducted at a range of 60$70^{\circ} \mathrm{C}$ (Mozafari, 2005), while Jahadi et al. (2012) used $50-60^{\circ} \mathrm{C}$ for optimization. Preparation of liposome in this study referred to the methods described by Dwiastuti et al. (2016).

\section{Physical appearance}

In this study, a factorial design with 2 factors and 3 levels was used. The response to be measured was particle size. Physical appearances of liposome prepared with variations of conditions are shown in Figure 1. Appearance of liposomes did not show 
differences in terms of color and turbidity. In each mixing condition, all of the resulting liposomes were yellow.

\section{Liposome size}

The formation of liposomes based on the presence of heat energy that alters the irregular lipid molecules, becomes planar and to a certain degree the energy can cause a curved shaping (Lasic, 1988; Mozafari, 2010). In this study, the energy that plays a role in the formation of liposomes is heat energy and sonication energy. Heat energy (above the transition temperature of lecithin) can increase fluidity of lipid molecules. Ultrasonic waves given during the sonication process are additional energies that can cause changes in lipid arrangement, which is initially irregular, planar, and then curved, to form liposomes.

The result of liposomes' size is shown in Table IV. The expected liposome size is less than $100 \mathrm{~nm}$ (Jufri, 2004). Liposome with size less than $100 \mathrm{~nm}$ can be produced using at least mixing temperature at $60^{\circ} \mathrm{C}$ and sonication duration for 30 minutes. Its size is $95.519 \pm 5.302$. Liposome size is decreased by increasing mixing temperature and sonication duration. It may happen because when the temperature increases, the system becomes more fluid and easy to break by sonication. Each phospholipid has their transition temperature. Soy lecithin has a transition temperature between $50-60^{\circ} \mathrm{C}$. At those temperatures, there is a transition phase, from the solid/gel phase becoming the liquid crystal phase. This transition causes the molecules to move freely and form a membrane.

The sonication process plays an important role in reducing the particles' size. Sonication will generate ultrasonic vibrations, which cause collisions between particles of liposomes in a medium to increase, meanwhile the ultrasonic waves can break down largesized liposomes to become smaller. Longer duration of sonication can affect the particle size because it can break the membrane and cause the liposomes to become smaller.

Dispersion solution of lecithin before sonication is very turbid. It is clearly different from the solution after sonication, which is less turbid. The more turbid a dispersion means that particle size is greater than the clear or foggy dispersion. It demonstrates that the sonication process can reduce the particle size of the liposomes.

Mixing in higher temperatures causes the fluidity of phospholipid layer to increase, so when it is exposed to ultrasonic waves during the process of sonication, the liposomes are more easily broken and form a liposome with smaller size.

\section{Polydispersity}

Polydispersity of liposome is measured to determine the homogeneity of liposome size. The polydispersity index in each variation can be observed in Table IV.

If the polydispersity index of a liposome is $<0.3$, it can be said that the liposome has a good homogeneity of liposomes' size (Badran, 2014). Table VI shows that in preparation of liposomes with mixing temperature and the duration of sonication at $60^{\circ} \mathrm{C}$ for 40 minutes and $70^{\circ} \mathrm{C}$ for 20 minutes, the polydispersity index obtained was more than 0.3 , so it was determined that in both conditions the homogeneity of liposomes' size was poor. This result might happen because the ultrasonic waves applied to the dispersion were not spread evenly when dispersion was sonicated (Winterhalter and Lasic, 1993).

\section{Analysis Data}

Results of liposomes size and polydispersity with different variations of the mixing temperature and sonication duration were analyzed using two-way ANOVA. The analysis results with two-way ANOVA are shown in Table $\mathrm{V}$. 
Table IV. Result of liposome size and polydispersity index

\begin{tabular}{cccc}
\hline $\begin{array}{c}\text { Duration of sonication } \\
\text { (minutes) }\end{array}$ & \multicolumn{3}{c}{ Liposome size $(\mathrm{nm})$ value on mixing temperature } \\
\hline 20 & $50^{\circ} \mathrm{C}$ & $60^{\circ} \mathrm{C}$ & $70^{\circ} \mathrm{C}$ \\
\hline 30 & $120.71 \pm 89.142$ & $106.114 \pm 1.747$ & $103.503 \pm 7.02$ \\
40 & $101.571 \pm 3.63$ & $95.519 \pm 5.302$ & $89.918 \pm 3.5$ \\
\hline $\begin{array}{c}\text { Duration of sonication } \\
\text { (minutes) }\end{array}$ & \multicolumn{4}{c}{ Liposome polydispersity index on mixing temperature } \\
\hline 20 & $50^{\circ} \mathrm{C}$ & $60^{\circ} \mathrm{C}$ & $70^{\circ} \mathrm{C}$ \\
\hline 30 & $0.292 \pm 0.026$ & $0.257 \pm 0.022$ & $0.309 \pm 0.041$ \\
40 & $0.257 \pm 0.025$ & $0.263 \pm 0.008$ & $0.274 \pm 0.034$ \\
\hline
\end{tabular}

Table V. Results of two-way ANOVA of liposome size and polydispersity

\begin{tabular}{lcc}
\hline \multicolumn{1}{c}{ Lource of Variation } & $\begin{array}{c}\text { P-value } \\
\text { Mean }\end{array}$ \\
\hline Sonication duration & $3.929 \mathrm{E}-08$ & Significant \\
Mixing temperature & $4.585 \mathrm{E}-06$ & Significant \\
Interaction & 0.4207716 & Not Significant \\
\hline & Polydispersity & \\
Source of Variation & P-value & Mean \\
\hline Sonication duration & 0.1059 & Not Significant \\
Mixing temperature & 0.8285 & Not Significant \\
Interaction & 0.1776 & Not Significant \\
\hline
\end{tabular}

Two-way ANOVA results show that each of the mixing temperature and sonication duration variations gives significant difference in particle size ( $p$-value is less than 0.05), but interaction of both treatments does not give significant difference ( $p$-value is more than 0.05). Whereas, mixing temperature, sonication duration and the interaction of both treatments do not give significant difference. These results show that each of the mixing temperature and sonication duration affects the liposomes' size produced, but does not affect the polydispersity of the liposomes.

\section{CONCLUSION}

Mixing temperature and sonication duration significantly affect particle size, but the interaction is not significant. Both mixing temperature and sonication duration do not affect polydispersity index of liposomes. Mixing temperature and sonication duration minimum that can produce liposomes with size below $100 \mathrm{~nm}$ is at $60^{\circ} \mathrm{C}$ for 30 minutes.

\section{REFERENCES}

Akbarzadeh, A., Sadabady, R., Davaran, S., Joo, S., Zarghami, N., Hanifehpour, Y., Samiei, M., Kouhi, M., Koshki, K., 2013. Liposome: Classification, Preparation, and Applications. Nanoscale Res. Lett., 8, 1-9.

Badran, M., 2014. Formulation and In Vitro Evaluation of Flufenamic Acid Loaded Deformable Liposome for Improved Skin Delivery. Dig. J. Nanomater. Biostruct., 9, 83-91.

Barenholz, Y., 2001. Liposome Application: Problems and Prospects. Curr. Opin. Colloid Interface Sci., 6, 66-77.

Colas, J.C., Shi, W., Rao, V.S.N.M., Omri, A., Mozafari, M.R., Singh, H., 2007. Microscopical Investigations of NisinLoaded Nanoliposomes Prepared by 
Mozafari Method and Their Bacterial Targeting. Micron, 38, 841-847.

Dwiastuti, R., Noegrohati, S., Istyastono, E.P., Marchaban, M., 2016. Metode Pemanasan dan Sonikasi Menghasilkan Nanoliposom dari Fosfolipid Lesitin Kedelai (Soy Lecithin). J. Pharm. Sci. Community., 13, 23-27.

Eloy, J.O., de Souza, M.C., Petrilli, R., Barcellos, J.P.A., Lee, R.J., Marchetti, J.M., 2014. Liposomes as Carriers of Hydrophilic Small Molecule Drugs: Strategies to Enhance Encapsulation and Delivery. Colloids Surf. B Biointerfaces., 123, 345-363.

Jahadi, M., Khosravi-Darani, K., Ehsani, M.R., Mozafari, M.R., Saboury, A.A., Seydahmadian, F., Vafabakhsh, Z., 2012. Evaluating the Effects of Process Variables on Protease-Loaded NanoLiposome Production by PlackettBurman Design for Utilizing in Cheese Ripening Acceleration. Asian J. Chem., 24, 3891-3894.

Jufri, M., 2004. Arah dan Perkembangan Liposome Drugs Delivery System. Maj. Ilmu Kefarmasian., 1, 59-68.
Kang, K.C., Lee, C.I., Pyo, H.B., Jeong, N.H., 2005. Preparation and Characterization of Nano-Liposomes using Phosphatidylcholine. J. Ind. Eng. Chem., 11, 847-851.

Knight, C., 1981. Liposomes: From Physical Structure to Therapeutic Applications.

Lasic, D.D., 1988. The Mechanism of Vesicle Formation. Biochem. J., 256, 1.

Machado, A.R., Assis, L.M., Machado, M.I.R., Souza-Soares, L.A., 2014. Importance of Lecithin for Encapsulation Processes. Afr. J. Food Sci., 8, 176-183.

Mozafari, M.R., 2010. Liposomes : Methods and Protocols.

Mozafari, M.R., 2005. Nanoliposomes: From Fundamentals to Recent Developments. Trafford Publishing.

Shashi, K., Satinder, K., Bharat, Prashar, 2012. A Complete Review on: Liposome. Int. Res. J. Pharm., 3, 10-16.

Winterhalter, M., Lasic, D.D., 1993. Liposome Stability and Formation: Experimental Parameters and Theories on the Size Distribution. Chem. Phys. Lipids., 64, 35-43. 